\title{
The professional developmental needs of higher education- based teacher educators: an international comparative needs analysis
}

\author{
Gerry Czerniawski $^{\mathrm{a} *}$, Ainat Guberman ${ }^{\mathrm{b}}$, Ann MacPhail ${ }^{\mathrm{c}}$ \\ ${ }^{a}$ The Cass School of Education and Communities, University of East London, London \\ UK; ${ }^{b}$ MOFET Institute, David Yellen College, Israel; ${ }^{c}$ University of Limerick, Ireland.
}

\begin{abstract}
A universal lack of attention to the professional learning needs of teacher educators is the driver for this study, which considers the most effective ways to support the professional learning of higher education-based teacher educators. At a time when many industrialised countries are engaged in systemic educational reform, this study provides an international and comparative needs analysis through a survey of 1,158 higher education-based teacher educators in the countries participating in the International Forum for Teacher Educator Development (InFoTED): Belgium, Ireland, Israel, the Netherlands, Norway and the UK. Our results suggest that while teacher educators are only moderately satisfied with their professional development experiences, a strong desire exists for further professional learning. This desire, influenced by their professional context, relates to their current beliefs concerning 'best practice' in teacher education, the academic skills required to further their professional careers and knowledge of the curriculum associated with their fields of expertise.
\end{abstract}

Keywords: Teacher education; professional development; professional learning; comparative education; teacher educators

\section{Introduction}

Teacher educators' professional learning tends to be positioned within a complex amalgam of the biography, identity work, skills, values and dispositions embedded within different learning communities (Czerniawski 2013; Feiman-Nemser 2001; Kosnik et al 2015). It is also positioned, to varying degrees, within wider international discourses reflecting the 
marketisation of public sector work, in which teacher education is often portrayed as a 'policy problem' (D. Mayer 2013). The 'ubiquitous availability of metrics concerning learning, performance and effectiveness' and the policy impact of international comparisons of educational achievement (Hargreaves 2014, 10) are two drivers with which nation-states battle as they engage in systemic educational reform. Teacher education, finally, has become part of their armoury. Driven by a desire to improve world rankings in educational league tables, changes in teacher training and education can be added to a list of reforms that attempt to secure greater value for money, to make education systems more responsive to the requirements of industry and commerce and to raise pupil achievement (Czerniawski 2010; Livingston and Robertson 2001). At the supranational level, the European Commission's recent policy gaze on teacher education has led to the Education Council adopting and enacting, for the first time, a European agenda for improving the quality of teacher education for all countries within the European Union (European Commission 2010, 2013, 2015). While this agenda is welcomed, it poses difficulties for those of us conceptualising and developing authentic professional learning opportunities for teacher educators at a time of systemic change. It also raises questions, in terms of professional learning, about what is meant by 'quality'.

In 2012 the International Forum for Teacher Educator Development (InFo-TED), an international group of leading teacher educators, came together to support the professional learning needs of teacher educators and to exchange best research, policy and practice (Vanassche et al 2015). The survey this article discusses forms part of ongoing work by InFoTED. We use 'teacher educator' as the inclusive term to encompass all who are professionally engaged in the initial and ongoing education of teachers, including school-based teacher educators. This broad definition follows that used by the European Commission (2013) which describes teacher educators as 'all those who actively facilitate the (formal) learning of student teachers and teachers' (8). However in this article we examine the professional learning needs of higher education-based teacher educators and will return to those of school-based teacher educators in future publications. Furthermore, while recognising the contestability of both terms, we use both professional development and professional learning as portmanteau terms to describe the formal and informal processes that enable teacher educators to improve their professional practice throughout their careers, with a commitment to transform education for the better. The article begins by familiarising the reader with competing definitions associated with teacher educators' professional development. The research design for the study is outlined and findings are presented and discussed in relation to the overarching themes that 
emerged in the survey analysis, namely: the professional learning activities teacher educators value and the factors that affect their participation in these activities.

\section{Teacher educators' professional learning}

Teacher educators' professional learning is under-researched, with much of the literature drawing on teachers' continuing professional development (CPD) in schools. Kennedy (2005), for example, has identified nine models of teachers' CPD in international literature, classified in relation to their capacity for supporting professional autonomy and transformative practice. These teacher-based models (training; award-bearing; deficit; cascade; standards-based; coaching and mentoring; community of practice; action research; transformative) have been usefully applied to literature on teacher educators' professional learning (see: Bates, Swennen and Jones 2011; Beauchamp et al. 2015). Mutual respect, risk-taking, a determination to improve, and professional, progressive discourse are factors cited as essential for effective professional learning (Schuck, Aubusson and Buchanan 2008). But these conditions need to be carefully scrutinised, with consideration given to the purpose of that professional learning.

Earley and Bubb (2004) distinguish 'hard' economic utilitarianism, where professional learning addresses the strategic goals of an institution, from a 'softer' developmental humanism in which professional development caters for valued, confident and motivated staff. This bifurcation is helpful when considering a further distinction made by Lipowski et al. (2011) between two forms of professional learning. The first goes under the banner of in-service programmes (i.e., organised programmes for practitioners within the institutions where they work), considered by some to be the primary way in which they receive continuing support (Loucks-Horsley et al. 1997). The second, labelled continuous experiential learning, accommodates the more informal learning opportunities that contribute to everyday professional practice. The importance of informal learning experiences (Livingston 2014; MacPhail et al. 2014) cannot and should not be underestimated when trying to understand the work teacher educators do in different national locations and the professional support they need.

Previous attempts to describe teacher educators' work (Ben-Peretz et al. 2010; Lunenberg, Dengerink and Korthagen 2014; Swennen, Jones and Volman 2010) have cited a variety of roles, each of which may require professional development: teaching, coaching, facilitation of 
collaboration between diverse organisations and stakeholders, assessment, 'gatekeeping', curriculum development, research and critical inquiry. The lack of induction into these roles experienced by so many teacher educators' is well documented (Murray, Czerniawski and Barber 2013; van Velzen et al. 2010). However, Griffiths, Thompson and Hryniewicz (2014) make a distinction between two groups of university-based teacher educators which adds further complexity to any professional learning needs analysis. Teacher educators from many anglophone countries often move into universities having previously taught in schools. This group is likely to have professional learning needs that differ from those of a second group from countries where teacher educators are drawn mainly from academic disciplines, often lacking practical teaching experience in schools (Griffiths, Thompson and Hryniewicz 2014). The two groups encounter different transitional experiences influencing their professional learning needs. In relation to these experiences, collaboration and collegiality are often positioned as processes, which are assumed to be benevolent and effective, underpinning effective professional learning (Hargreaves 1994; Livingston 2014). However, in a comparative needs analysis such as this study, it is important to acknowledge that these terms have also been used to describe a form of contrived collegiality (Hargreaves 1994) said to exist in more highly regulated, compliant and audited education systems as a more efficient way of introducing externally imposed changes (Czerniawski 2013).

\section{This study}

At present, there are few systemic routes for teacher educators' ongoing learning, and little research documentation of these (Berry 2013; Murray, Czerniawski and Barber 2011; Smith 2012). Given the unique occupational position of teacher educators and the lack of formal focus on their professional learning, our starting point lies in their practice positioned within local, national, regional and global policy contexts. According to the European Commission (2012), 'if teachers are the most important in-school factor influencing the quality of students' learning, the competences of those who educate and support teachers (teacher educators) must be of the highest order' (52). Building on the recommendations of two European Commission reports that promote and support a shared vision and common understanding of what is meant by 'quality' in educating teachers and access to high-quality opportunities for CPD (European Commission 2012, 2013), this study addresses two main research questions:

1. What professional learning activities do higher education-based teacher educators value? 
2. How best can these activities be realised?

The research questions for this study are significant when considering that many teacher educators acquire their expertise after taking on the position of teacher educator, especially if their background lies solely in either school teaching or research (Murray and Male 2005; Smith 2012).

\section{Method}

\section{Participants}

Participants were recruited through the institutions in which they worked and through professional networks. The participants were 1,158 teacher educators working in higher education institutions, from six countries: Belgium (176, 16.6\%), Ireland (54, 5.1\%), Israel $(101,9.5 \%)$, the Netherlands $(358,33.8 \%)$, Norway $(76,7.2 \%)$ and the UK $(294,27.8 \%)$.

Background variables are presented both in raw numbers and as valid percentages, excluding respondents with missing data. There were $313(31.3 \%)$ males and $688(68.7 \%)$ females (157 participants did not state their gender). The median age group was 45-54 years old (age groups ranged from less than 25 to older than 64). The number of years' experience as teacher educators ranged from 0 to 47, with a mean of 11.99 years $(\mathrm{SD}=8.77)$. In total, $908(78.5 \%)$ indicated they had experienced teaching before being recruited as teacher educators. Participants included 341 (34.0\%) PhD or EdD holders, 599 (59.6\%) Master's degree holders, $61(6.1 \%)$ with BA/BSc, and $3(0.03 \%)$ with non-academic qualifications (additional 154 provided no information on academic qualifications). Most of the participants $(819,81.8 \%)$ had permanent positions, and almost two-thirds $(638,63.5 \%)$ worked as teacher educators full time.

\section{Procedure}

A questionnaire was constructed and distributed in English in all participating countries in the InFo-TED network except in the Netherlands and Belgium, where it was translated and distributed in Dutch. While most of the respondents filled in the questionnaire online, all the participants (176) from Belgium, 126 from the Netherlands and 24 from Israel filled in a paperand-pencil version. All surveys are included in the sample reported here.

\section{The questionnaire}


Professional learning needs were assessed by a questionnaire that had four sections: professional learning preferences (31 items); factors considered before a professional learning activity is engaged in ( 8 items); research dispositions and experience (4 items); role description and background information (28 items).

Participants rated on a Likert response scale, ranging from 1 (= not at all) to 6 (= very much), their level of satisfaction with the professional learning opportunities they have had (1 item), their degree of interest in further professional learning (1 item) and their degree of interest in specific professional learning options (27 items). Participants also provided qualitative responses to two survey questions - 'What are your two most important professional learning needs?' and 'What professional learning opportunities would best meet these needs?' The qualitative data for each question was analysed separately for the 624 participants that provided responses in English.

All responses to each question were recorded in separate documents. The comments were manually reviewed and continually coded, noting similarities and differences, groupings, patterns and items of particular significance (Rubin \& Rubin, 1995). All comments appear only once in what is deemed to be the most suitable category. Table 4 denotes the identified codes and their frequency arising from teacher educators' most important professional learning needs. Responses to the specific professional development options were subjected to principal component factor analysis with Kaiser Varimax (orthogonal) rotation yielding two main factors, presented in Table 1 (factor analysis is a statistical method used to reduce a multitude of variables by analyzing the correlations among these variables). The first factor, 'Academic Interest' (13 questionnaire items), comprises activities characteristic of research universities (e.g., reviewing papers and presenting at conferences), whereas the second factor, 'Educational Interest' (12 items), comprises activities and content areas specific to teaching and teacher education (e.g., curriculum development and assessment). Together, these two factors account for $37.80 \%$ of the variance among 25 of the 27 items that refer to specific options for professional learning. Two items did not load on any of these factors (i.e., were not correlated with any of them): interest in online learning and specialisation in academic administration.

\section{[Insert Table 1 near here]}

The authors acknowledge the limitations of an article of this nature, not least, the extent to which it is able to address the in-depth specificities of teacher educators' professional learning on a country-by-country basis. However the first part of this ongoing study, reported here, 
begins to address the lack of research into the professional development of teacher educators and, moreover, to determine what is effective in supporting them in their professional growth (Lunenberg, Dengerink and Korthagen 2014). Follow-up interviews with a sample of teacher educators from this study in each of the participating countries will, in future publications, provide greater insight into the relationship between professional learning opportunities and the learning processes and outcomes gained from these.

\section{Results}

Are higher-education-based teacher educators interested in professional learning?

The mean value of satisfaction with past opportunities for professional learning was moderately positive: 4.01 ( $\mathrm{SD}=1.23$ ), with $72 \%$ expressing satisfaction. Men were more satisfied with the professional learning opportunities they have had than were women (4.19 vs. 3.93; $\mathrm{F}(1$, $915)=5.65, p<.05)$. There were no significant differences by other background variables: academic qualifications (Master's vs. doctorate), employment (full-time vs. part-time position) or experience (up to the median of 10 years vs. more than 10 years of experience).

The mean value of interest in future professional learning activities was high: $4.85(\mathrm{SD}=1.08)$, with $89 \%$ expressing positive (i.e., 4-6) attitudes, implying there is a genuine need for professional learning among teacher educators. Women were more interested in professional learning activities than were men (4.84 vs. 4.51; $\mathrm{F}(1,917)=13.38, \mathrm{p}<.001)$, Master's degree holders were more interested than those with a doctorate $(4.81$ vs. $4.54 ; \mathrm{F}(1,917)=8.29, \mathrm{p}<.01)$, teacher educators with up to 10 years' experience were more interested than those with longer experience ( 4.77 vs. $4.58 ; \mathrm{F}(1,917)=4.46, \mathrm{p}<.05)$, and those working full time as teacher educators were more interested than those working part time $(4.84$ vs. $4.51 ; \mathrm{F}(1,917)=12.69$, $\mathrm{p}<.001$ ), implying that teacher educators form a very heterogeneous group.

What professional learning activities do higher education-based teacher educators value?

Respondents were much more interested in professional learning activities addressing teaching and learning $(\mathrm{M}=4.80, \mathrm{SD}=1.12)$ than in those addressing research and writing skills $(\mathrm{M}=3.84, \mathrm{SD}=1.38, \mathrm{t}(999)=20.40, \mathrm{p}<.001)$. Table 2 presents the simultaneous regression analysis performed to examine the effects of background variables upon the participants' 
professional learning interests. Women were more interested than men in both types of activities, academic and educational.

\section{[Insert Table 2 near here]}

The Academic Interest scale was correlated with participants' academic qualifications: doctorate holders were more interested in these activities than master's degree holders. Fulltime position holders were more interested than part-time employees. The Educational Interest scale was inversely correlated with participants' academic qualifications and experience: Master's degree holders were more interested in educational activities than doctorate holders, and teacher educators with up to 10 years' experience were more interested in educational activities than those with longer experience.

The specific professional learning opportunities the participants rated are presented in Table 3 . The mean level of interest in the Academic as well as the Educational Interest scales was positive, yet not very high ( $\mathrm{M}=4.07$ and $4.21, \mathrm{SD}=.82$ and .76 , respectively). The only activities that attracted a high level of interest (above 4.5 on the 6-level Likert response scale) were: personal reading, informal learning conversations with other colleagues, visits to other schools and teacher education institutions, learning about current developments in teacher education, and performing practitioner-based research (e.g., action research).

\section{[Insert Table 3 near here]}

Most important professional learning needs and associated professional learning opportunities

In addition to the above-mentioned professional learning opportunities, participants were asked to note their two most important professional learning needs. Table 4 notes the professional learning codes that arose from categorising the responses, and the frequency with which responses to each code were made.

\section{[Insert Table 4 near here]}

Participants were subsequently asked to identify the professional learning opportunities that would most effectively address the identified needs. Given limited space in which to unpack each of the codes listed in Table 1, we engage further with the top five professional learning needs identified by the participants and the professional learning opportunities that they recorded as being the most effective at addressing those needs. 


\section{Availability (or not) of time}

Not surprisingly, time is consistently noted as one of the most important professional learning needs for teacher educators. The tasks most frequently identified as requiring more time were related to engaging in scholarly activity such as reading research, conducting research, academic writing and thinking. There were also suggestions that institutions should provide a realistic time allocation to research-related activities as an incentive. Other tasks requiring more time that would contribute to teacher educators' more general professional learning included reading widely across disciplines, discussions with colleagues on teaching practices, values and philosophies as well as on the incorporation of new programmes and associated pedagogies.

As might be expected, when participants were asked to consider the most effective way to address the time issue, typically the answer was framed in terms of 'time' itself, exemplified by one teacher educator wanting 'Time and a reduced workload. I am not being flippant here. I have neither the time nor the energy to attend development and learning sessions'. Sabbatical and/or sabbatical-related activity was the second most frequent response, with teacher educators wanting to undertake a period of study leave, attend writing retreats or study abroad. Managing workload better was the third most frequent response. Teacher educators voiced a desire for assistance from managers in organising and freeing up time for research within an already high (predominantly teaching) workloads.

\section{Research skills}

A significant number of teacher educators commented on their need to develop their research skills in the areas of writing, research methodology and methods, research ethics and data analysis. There was a need for assistance at two levels. One level included how to conduct research and develop a research portfolio, how to access and engage in small-scale research, how to write for "the "right" journals', how to locate conferences and integrate research into their lectures. A second level related to those who wished to extend their research profile to international audiences as well as contribute to country-specific research exercise frameworks.

When asked the most effective way to improve research skills, research seminars, courses and workshops were commonly cited options. Participants desired opportunities to develop specific research skills related to their areas of interest, in preference to longer, more generic research training opportunities. Opportunities to up-skill online were mentioned as an alternative to attending classes, with the former enabling participants to further develop their skills at times 
that suited them. Collaborating with experienced colleagues (including doctoral supervisors) was the second most popular response, closely followed by the opportunity to work with, and receive support from, groups. The latter was portrayed as an opportunity to discuss research papers, share how best to engage with research and writing and access colleagues across a range of universities.

\section{Use of ICT/online learning/social media}

The third most frequent professional learning need focused on how best to use digital technologies for enhanced teaching and learning in a bid 'to meet the 21 st century needs'. Online learning and associated materials were mentioned, with an interest in teaching platforms that integrate on-line materials into everyday teaching. Social networking and social media were also mentioned as forums through which teacher educators believed they could support teaching and student learning.

By far the most frequent response to how best to address the professional learning need of using ICT and related practices was the need for courses and training workshops. While a number of suggestions were made (e.g., preparing online teaching materials and familiarity with social media), participants focused more on the form such delivery should take. There was a preference for training activities either online or within their own institution, targeted towards specific needs identified by attendees of such training: 'purpose built and individually targeted teaching sessions'. Personal coaching and mentoring from a professional peer/colleague was also suggested.

\section{Publish research/academic writing}

The need to publish research and/or write for publication was again noted at two distinct levels. One group of participants conveyed the need to begin writing for publication, seeking direction on how best to develop ideas and subsequently transform ideas into a publication, as well as understanding more about the publishing process. Another group appeared to have some level of experience in publishing, alluding to the need to increase their publication rate, develop a higher quality of publication and consider how to write for different audiences.

Coaching and mentoring were closely followed by collaborating with (experienced) colleagues as suggestions on how best to address the professional learning need of publishing research/pursuing academic writing. With respect to coaching and mentoring, one teacher educator echoed the request of others when proposing 'Allocation of a mentor to help support 
and advise from a research background'. With respect to collaborating with (experienced) colleagues, related activities included peer learning, working on specific publications with colleagues and working in a writing group. One teacher educator clearly articulated their hopes for such collaboration: 'Shadowing a more experienced colleague who would write a paper or carry out a small scale research with me in order that I can learn from them before having a go and being supported by them as a mentor for a 2nd paper'.

\section{Consideration of pedagogical principles/delivery}

A clear impression was given that teacher educators wished to learn ways in which to improve teaching and learning without compromising their responsibility for delivering all areas of the curriculum. Participants were explicit in their specific needs related to pedagogy and associated delivery. Needs included up-skilling in new pedagogies associated with particular subject disciplines, developing more generic teaching and learning strategies (e.g., active teaching approaches, integrating theory and practice, self-directed learning, feedback, flipping the classroom) and consideration of class management (e.g. managing large class sizes, managing different learning needs, managing different populations such as disadvantaged students). A number of teacher educators stated that they were relatively new to their current post and yet to become familiar with the courses, procedures and systems they were now to deliver.

The types of responses to how best to address the professional learning need of improving teaching and learning revolved, in similar quantities, around university courses, workshops, seminars, conferences and initial teacher education colleagues. Not dissimilar to the requests made for ICT skill development, teacher educators wanted in-house courses tailored to their specific teaching needs. With respect to colleagues, teacher educators sought opportunities to observe colleagues and have them observe and feed back to them as well as have time with colleagues to share experiences and develop ideas.

\section{Discussion}

In the introduction to this article we referred to a European agenda aiming to improve the quality of teacher education and how this, while welcomed, raises questions in terms of teacher educators' professional learning and what might be meant by 'quality'. In the race to improve world rankings in educational league tables, to secure greater value for money, and to raise levels of pupil achievement, we hope that 'quality' in this context avoids the belief that good 
professional learning equates to narrow, instrumental concerns over university world-rankings and embraces more humanistic forms of professional learning. This study is important not just for teacher educators but all politicians, policy makers and practitioners who believe that the quality of teaching affects the quality of learning. As professional learners themselves, only teacher educators can ensure such quality is nurtured, maintained, developed and perfected.

But professional contexts vary and teacher educators, as stated earlier, are far from being a homogenized professional group. Although many publications describe the multitude of roles teacher educators assume (e.g. Berry 2013; Goodwin and Kosnik 2013; Loughran 2014), this study provides data to question the extent to which all those working in higher education can ever develop an integrated professional profile, i.e., that of a teacher/practitioner and researcher. A number of factors impede the development of that profile. It is clear from both the quantitative and qualitative survey data that, while teacher educators consistently appear to value professional learning, divergence exists in their priorities and needs. Two types of teacher educators' professional learning needs arise from the data: (i) those involving the development of educational capacities related to their day-to-day remit as a teacher educator (for example in the delivery of taught programmes) and (ii) those required for progressing an academic career, with research and writing skills being the most salient. It is also clear that many teacher educators strive to improve their current strengths rather than seek further professional development in areas in which they have limited or no experience. A difference exists, for example, in the type of professional needs identified by those with a Master's degree (which were more aligned to teacher educators' educational capacities) and those with a PhD (more aligned to scholarly activities to progress an academic career). These divisions can, in part, be explained by the two distinct policies for recruiting teacher educators referred to earlier, namely the recruitment of teachers from schools and/or the recruitment of teachers from a predominantly research background.

The need for opportunities to generate critical and collaborative professional learning conversations has previously been supported in the literature (Hoban 2002; Loughran 2006), with research beginning to explore specifically professional learning/development communities for teacher educators (Hadar and Brody 2010; MacPhail et al. 2014). This study builds on this literature emphasizing the ways in which teacher educators, as both teachers and researchers, want to be part of a collaborative community where they can feel supported, listened to, and share their practices and experiences. However those practices and experiences vary depending on the professional identity, and trajectory of the teacher educator. The extent 
to which collaborative communities can operate successfully is dependent on the human and material resources available to those seeking professional development opportunities. For example, numerous requests were made by both full-time and part-time teacher educators to reconfigure current workloads to allow them space to engage in professional learning. While some admitted managing their time efficiently, the majority of comments called for management of higher-education institutions to acknowledge high (predominantly teaching) workloads and subsequently find ways to incorporate time for professional learning. Regardless of the type of development need, or whether teacher educators came from a schoolteaching or 'academic' [sic] background, participants in this study expressed a strong preference for professional learning opportunities that are continuous and based around experiential learning (e.g., working collaboratively with, and observing colleagues/experienced researchers; being mentored; being part of a team). However for both groups to effectively share their practices and experiences in future there is much work to be done in the siloed organizational cultures that are currently found in many higher educational institutions (Anderson et al. 2015).

Allocating designated time for proper induction and professional learning would enable policymakers and higher education institutions to encourage teacher educators to acquire and develop a more diversified and balanced, integrated professional profile rather than expect them to achieve this on their own. Furthermore, working collaboratively within such designated time slots will help teacher educators to create their own distinct and coherent professional identity (rather than through policy-makers' enforced reforms) and further develop their profession.

\section{Concluding thoughts}

The research methods used in this study, part of ongoing wider research by the InFo-TED network (see: Vanassche et al 2015), reveal that in all six countries a strong desire exists from teacher educators to be exposed to alternative ways to educate teachers, to learn about developments in teacher education policy and contribute to teacher education research literature. There is much to learn from, and in, countries where the professional learning of teacher educators is strongly supported. So too is there in countries where such support is relatively lacking. The overriding finding from the survey is that teacher educators have a genuine passion to learn with and from colleagues and peers, and to become part of a learning community of like-minded individuals, albeit with different professional trajectories. This is 
conveyed as the strongest contribution to the consolidation of the teacher education profession and its continued development. Such a positive disposition from teacher educators may in fact enhance the possibility of working towards agreed expectations for teacher education professional learning development plans.

\section{References}

Anderston, C., Y. Foley and P. Sangster. 2015. Teacher education cultures and enviornments. ESRC December 2015 Briefing Paper - Teacher Education for the Changing Demographics of Schooling: policy, practice and research. http://www.ed.ac.uk/files/atoms/files/briefing_paper___seminar_6.pdf

Bates, T., A. Swennen and K. Jones. 2011. The Professional Development of Teacher Educators. London: Routledge.

Beauchamp, G., L. Clarke, M. Hulme, M. Jephcote, A. Kennedy, G. Magennis, and I. Menter. 2015. Teacher Education in Times of Change. Bristol: Policy Press.

Ben-Peretz, M., S. Kleeman, R. Reichenberg and S. Shimoni. 2010. "Educators of Educators: Their Goals, Perceptions and Practices". Professional Development in Education 36 (1-2), $111-129$.

Berry, M. 2013. “Teacher Educators' Professional Learning: 'You're More or Less on Your Own'”. Paper presented at the 16th Biennial Conference of ISATT (International Study Association on Teachers and Teaching), Ghent, Belgium, July 2-7.

Czerniawski, G. 2010. Emerging Teachers and Globalisation. New York: Routledge.

Czerniawski, G. 2013. "Professional Development for Professional Learners: Teachers' Experiences in Norway, Germany and England". Journal of Education for Teaching 39 (4): 383-399.

Earley, P., and S. Bubb. 2004. Leading and Managing Continuing Professional Development: Developing Teachers, Developing Schools. London: Sage/Paul Chapman.

European Commission. 2010. Improving Teacher Quality: The EU Agenda - Lifelong Learning: Policies and Programme. EAC.B.2. D (2010) PSH. Brussels: European Commission. 
European Commission. 2012. Supporting the Teaching Professions for Better Learning

Outcomes. Commission Staff Working Document SWD (2012) 374. Strasbourg: European Commission.

European Commission. 2013. Supporting Teacher Educators for Better Learning Outcomes. Brussels: European Commission.

European Commission. 2015. "Strengthening Teaching in Europe: New Evidence from Teachers compiled by Eurydice and CRELL, June 2015”. http://ec.europa.eu/education/library/policy/teaching-profession-practices_en.pdf

Feiman-Nemser, S. 2001. "From Preparation to Practice: Designing a Continuum to Strengthen and Sustain Teaching". Teachers College Record 103: 1013-1055.

Goodwin, A. L., and C. Kosnik. 2013. "Quality Teacher Educators = Quality Teachers? Conceptualizing Essential Domains of Knowledge for Those Who Teach Teachers." Teacher Development: An International Journal of Teachers' Professional Development 17 (3): 334 346.

Griffiths, V., S. Thompson and L. Hryniewicz. 2014. "Landmarks in the Professional and Academic Development of Mid-Career Teacher Educators". European Journal of Teacher Education 37 (1): 74-90.

Hadar, L., and D. Brody. 2010. "From Isolation to Symphonic Harmony: Building a Professional Development Community among Teacher Educators". Teaching and Teacher Education 26, 1641-1651.

Hargreaves, A. 1994. Changing Teachers, Changing Times. London: Cassell.

Hargreaves, A. 2014. "Foreword: Six Sources of Change in Professional Development". In Handbook of Professional Development in Education, edited by L. Martin, S. Kragler, D. J. Quatroche and K. L. Basuerman. New York: Guildford.

Hoban, G. F. 2002. Teacher Learning for Educational Change: A Systems Thinking Approach. Buckingham: Open University Press.

Kosnik, C., Dharmashi, P., Miyata, C., Cleovoulou, Y., \& Beck, C. 2015. Four spheres of knowledge required: An international study of the professional development of literacy/English teacher educators. Journal of Education for Teaching 4(1), 52-77. 
Lipowski, K., D. Jorde, M. Prenzel and T. Seidel. 2011. "Expert Views on the Implementation of Teacher Professional Development in European Countries". Professional Development in Education 37 (5): 685-700.

Livingston, K. 2014. "Teacher Educators: Hidden Professionals?" European Journal of Education 49 (2): 218-232. doi:1111/ejed.12074.

Livingston, K., and J. Robertson. 2001. "The Coherent and the Empowered Individual: Continuing Professional Development for Teachers in Scotland”. European Journal of Education 24 (2): 184-194.

Loucks-Horsley, S., P. W. Hewson, N. B. Love and K. E. Stiles. 1997. Designing Professional Development for Teachers of Science and Mathematics. Thousand Oaks, CA: Corwin.

Loughran, J. J. 2006. Developing a Pedagogy of Teacher Education: Understanding Teaching and Learning about Teaching. Abingdon: Routledge.

Loughran, J. 2014. "Professionally Developing as a Teacher Educator". Journal of Teacher Education 65 (4), 271-283.

Lunenberg, M., J. Dengerink and F. Korthagen. 2014. The Professional Teacher Educator: Roles, Behaviour, and Professional Development of Teacher Educators. Rotterdam: Sense Publishers.

MacPhail, A., K. Patton, M. Parker and D. Tannehill. 2014. "Leading by Example: Teacher Educators' Professional Learning through Communities of Practice”. Quest 66: 39-56.

Murray, J., and T. Male. 2005. "Becoming a Teacher Educator: Evidence from the Field". Teaching and Teacher Education 21: 125-142.

Rubin, H.J. and Rubin, I.S. (1995) Qualitative Interviewing: The Art of Hearing Data. London: SAGE.

Schuck, S., P. Aubusson and J. Buchanan. 2008. "Enhancing Teacher Education Practice through Professional Learning Conversations”. European Journal of Teacher Education 31 (2): $215-227$.

Smith, K. 2012. “The Multi-Faceted Teacher Educator: A Norwegian Perspective”. Journal of Education for Teaching: International Research and Pedagogy, 37 (3), 337-349. 
Swennen, A., K. Jones and M. Volman. 2010. "Teacher Educators: Their Identities, SubIdentities and Implications for Professional Development". Professional Development in Education 36 (1-2), 131-148.

Vanassche, E., F. Rust, P.F. Conway, K. Smith, H. Tack and R. Vanderlinde. 2015. "InFoTED: Bringing Policy, Research and Practice Together Around Teacher Educator Development. In Advances in Research on Teaching, edited by C. J. Craig and L. OrlandBarak.

Van Velzen, C.M., A. van der Klink, A. Swennen and E. Yaffe. 2010. "The Induction Needs of Beginning Teacher Educators". Professional Development in Education 36 (1): 61-75.

Acknowledgement: We would like to thank Dr. Rachel Sagee of the Mofet Institute in Israel and members of InFo-TED for their advice and guidance in the construction of the survey.

\section{Tables for inclusion with this article}

Table 1. Component loading of interests in professional development

\begin{tabular}{lcc}
\hline & Academic & Educational \\
& Interest & Interest \\
\hline Academic writing & .80 & -.13 \\
Conference presentations & .80 & -.04 \\
Scholarly writing & .71 & .17 \\
\hline
\end{tabular}




\begin{tabular}{|c|c|c|}
\hline Empirical research (non-practitioner based) & .70 & .04 \\
\hline $\begin{array}{l}\text { Reviewing journal articles, conference abstracts } \\
\text { etc. }\end{array}$ & .64 & .25 \\
\hline Research skills & .61 & .29 \\
\hline Action research/practitioner-based research & .57 & .29 \\
\hline Presentation and participation at conferences & .57 & .33 \\
\hline Participation in professional organisations & .54 & .23 \\
\hline International exchanges/visits & .50 & .18 \\
\hline Secondment/sabbatical & .47 & -.04 \\
\hline Personal reading (e.g., books, journals etc.) & .44 & .23 \\
\hline Award-bearing courses & .41 & .24 \\
\hline Current developments in teacher education & .18 & .70 \\
\hline Curriculum development & .16 & .68 \\
\hline Assessment & .17 & .68 \\
\hline Coaching and mentoring student teachers & -.03 & .68 \\
\hline Subject knowledge enhancement & -.01 & .62 \\
\hline $\begin{array}{l}\text { Integrating technology into teaching and learning } \\
\text { strategies }\end{array}$ & .06 & .58 \\
\hline Training activities within the institution & .08 & .56 \\
\hline Peer coaching & .23 & .52 \\
\hline Researching my own practice & .39 & .51 \\
\hline Visits to other schools/teacher education & .32 & .45 \\
\hline Observation by/of colleagues & .09 & .45 \\
\hline Informal learning conversations with other & .16 & .44 \\
\hline Eigenvalues & 5.40 & 4.80 \\
\hline Percentage of total variation & 20.01 & 17.79 \\
\hline Number of items & 13 & 12 \\
\hline Scale reliability (Cronbach's alpha) & .86 & .84 \\
\hline
\end{tabular}


The Likert response scale ranges between 1 (not at all) and 6 (very much). 
Table 2.

Simultaneous regression analysis predicting interest in professional development

\begin{tabular}{lcccccc}
\hline \multirow{2}{*}{ Variable } & \multicolumn{3}{c}{ Academic Interest } & \multicolumn{3}{c}{ Educational Interest } \\
\hline Gender & $\mathrm{B}$ & $\mathrm{SE}$ & $\beta$ & $\mathrm{B}$ & $\mathrm{SE}$ B & $\beta$ \\
Degree & .24 & .06 & $.14^{* * *}$ & .26 & .05 & $.16^{* * *}$ \\
Employment & .24 & .05 & $.14^{* * *}$ & -.26 & .05 & $-.17^{* * *}$ \\
Experience & .29 & .05 & $.17^{* * *}$ & .03 & .05 & .02 \\
\hline Intercept & -.10 & -.06 & -.06 & -.20 & .05 & $-.13^{* * *}$ \\
$\mathbf{R}^{2}$ & 3.60 & .07 & & 4.33 & .12 & \\
\hline
\end{tabular}

$* \mathrm{p}<.05, * * \mathrm{p}<.01, * * * \mathrm{p}<.001$ 
Table 3. Preferences for professional development activities

M

SD

$\mathbf{N}$

ACADEMIC INTEREST

Personal reading (e.g., books, journals, etc.)

$\begin{array}{lll}5.03 & .86 \quad 998\end{array}$

Action research/practitioner-based research

$\begin{array}{lll}4.53 & 1.12 \quad 994\end{array}$

International exchanges/visits

$\begin{array}{lll}4.43 & 1.21 \quad 990\end{array}$

Participation in professional organisations

$4.39 \quad 1.16 \quad 994$

Empirical research (non-practitioner based)

$\begin{array}{lll}4.23 & 1.18 & 987\end{array}$

Conference presentations

$\begin{array}{lll}4.16 & 1.30 \quad 988\end{array}$

Secondment/sabbatical

$\begin{array}{lll}4.06 & 1.44 \quad 981\end{array}$

Academic writing

$\begin{array}{lll}4.04 & 1.41 \quad 995\end{array}$

Award-bearing courses

$\begin{array}{lll}4.00 & 1.36 \quad 981\end{array}$

Research skills

$\begin{array}{lll}3.88 & 1.49 & 992\end{array}$

Scholarly writing

$3.61 \quad 1.59 \quad 983$

Presentation and participation at conferences

$\begin{array}{lll}3.35 & 1.50 \quad 986\end{array}$

Reviewing journal articles, conference abstracts etc.

$\begin{array}{lll}3.22 & 1.51 \quad 979\end{array}$

EDUCATIONAL INTEREST

Informal learning conversations with other colleagues

$\begin{array}{lll}4.84 & .98 & 998\end{array}$

Visits to other schools/teacher education institutions

$\begin{array}{lll}4.69 & 1.05 \quad 993\end{array}$

Current developments in teacher education

$\begin{array}{lll}4.62 & 1.13 \quad 998\end{array}$

Peer coaching

$\begin{array}{lll}4.18 & 1.18 \quad 991\end{array}$

Curriculum development

$\begin{array}{lll}4.15 & 1.31 \quad 991\end{array}$

Observation by/of colleagues

$\begin{array}{lll}4.14 & 1.28 & 990\end{array}$

Researching my own practice 
Training activities within the institution (not award-

bearing)

$\begin{array}{lll}4.09 & 1.19 \quad 990\end{array}$

Assessment

$\begin{array}{lll}4.01 & 1.32 & 987\end{array}$

Subject knowledge enhancement

$\begin{array}{lll}4.00 & 1.40 \quad 1002\end{array}$

Integrating technology into teaching and learning

$\begin{array}{lll}3.89 & 1.33 \quad 996\end{array}$

Coaching and mentoring student teachers

$\begin{array}{lll}3.87 & 1.44 \quad 998\end{array}$

Other

Online learning

$3.67 \quad 1.25 \quad 991$

Specialisation in academic administration

$2.57 \quad 1.44 \quad 982$

The Likert response scale ranges between 1 (not at all) and 6 (very much). 
Table 4: $\quad$ Identified codes and frequency of related codes arising from teacher educators' most important professional learning needs

\begin{tabular}{ll}
\hline Code & Frequency \\
\hline Research skills & 170 \\
Publish research / academic writing & 78 \\
Consideration of pedagogical principles / delivery & 137 \\
Availability (or not) of time & 90 \\
Use of ICT / online learning / social media & 80 \\
Awareness of current policies in teacher education & 39 \\
Networks and networking for teaching and research & 27 \\
Support for particular aspects of the job & 23 \\
Developing subject specific knowledge & 18 \\
Transitioning into teacher education & 8 \\
Accessing literature & 7 \\
Project management & 6 \\
\hline
\end{tabular}

